\title{
JENIS-JENIS ANGGREK (ORCHIDACEAE) DI HUTAN RAWA GAMBUT KABUPATEN BELITUNG
}

\author{
Selviana ${ }^{1}$, Eddy Nurtjahya ${ }^{1} \&$ Diah Sulistiarini ${ }^{2}$ \\ ${ }^{1}$ Program Studi Biologi, Fakultas Perikanan dan Biologi, Universitas Bangka Belitung \\ ${ }^{2}$ Bidang Botani, Pusat Penelitian Biologi, Lembaga Ilmu Pengetahuan Indonesia, Cibinong 16911
}

Selviana, Eddy Nurtjahya \& Diah Sulistiarini. 2019. Orchids Species (Orchidaceae) in Peat Swamp Forest of Belitung Regency. Floribunda 6(2): 72-80. — Orchid is one of the plant groups that has high commercial value. The orchid's diversity in Belitung Island, particularly in the peat swamp forest has never been collected before. The purpose of this research is to identify wild orchid species from three locations in Belitung Region. The identification was in Herbarium Bangka Belitungense and Herbarium Bogoriense (BO), Research Center for Biology-LIPI, Cibinong. The result of the research states that 9 species of orchids from 6 genus are found which are divided into 6 species of epiphytic orchids and 3 species of terrestrial orchids. The most common species found in the area is from the genus Bulbophyllum Thou, Dendrobium Sw. and Plocoglottis Blume. A newly recorded species is also recognized from the genus Thecopus, i.e. Thecopus secunda.

Keywords: Belitung Region, Orchidaceae, peat swamp forest.

Selviana, Eddy Nurtjahya \& Diah Sulistiarini. 2019. Jenis-jenis Anggrek (Orchidaceae) di Hutan Rawa Gambut Kabupaten Belitung. Floribunda 6(2): 72-80. — Anggrek salah satu tumbuhan yang memiliki nilai komersial tinggi. Data keanekaragaman anggrek di Pulau Belitung, khususnya di hutan rawa gambut Kabupaten Belitung belum pernah dilakukan. Penelitian ini bertujuan untuk mengidentifikasi jenis-jenis anggrek alam yang ada di hutan rawa gambut Kabupaten Belitung. Penelitian dilakukan di hutan rawa gambut, Kabupaten Belitung dengan 3 lokasi. Identifikasi dilakukan di Herbarium Bangka Belitungense dan Herbarium Bogoriense (BO), Pusat Penelitian Biologi-LIPI, Cibinong. Berdasarkan hasil penelitian, ditemukan 9 jenis anggrek dari 6 marga, terdiri dari 6 jenis anggrek epifit, 3 jenis anggrek terestrial. Jenis yang paling banyak dijumpai di daerah tersebut adalah dari marga Bulbophyllum Thou., Dendrobium Sw. dan Plocoglottis Blume, serta terdapat satu anggrek rekaman baru yaitu jenis Thecopus secunda.

Kata kunci: Kabupaten Belitung, Orchidaceae, hutan rawa gambut.

Anggrek adalah tumbuhan yang memiliki nilai komersial tinggi (Lestari \& Santoso 2011), serta merupakan jenis tumbuhan hias yang memiliki bunga dengan mahkota indah dan warna menarik. Oleh karena itu, anggrek menjadi primadona di kalangan petani dan pecinta tumbuhan hias (Agustin \& Widowati 2015).

Daerah persebaran anggrek sangatlah luas, sebanyak 26.000 jenis anggrek yang ada di dunia dan diperkirakan di Indonesia ada 5.000 jenis (Indarto 2011). Sedangkan Widjaja et al. (2014) menyatakan bahwa hingga akhir 2013 ada sekitar 7.622 jenis anggrek yang tumbuh alami di kawasan Indonesia.

Bangka Belitung merupakan salah satu provinsi kepulauan di Indonesia yang terletak di selatan Pulau Sumatra dengan gugusan dua pulau yaitu Pulau Bangka dan Pulau Belitung. Salah satu kawasan di Pulau Belitung yang diharapkan masih banyak menyimpan potensi tumbuhan anggrek adalah Kabupaten Belitung. Secara geografis Ka- bupaten Belitung terletak antara $107^{\circ} 08^{\prime} \mathrm{BT}$ sampai $107^{\circ} 58^{\prime} \mathrm{BT}$ dan $02^{\circ} 30^{\prime} \mathrm{LS}$ sampai $03^{\circ} 15^{\prime} \mathrm{LS}$ dengan luas daratan seluruhnya 229.369 ha yang sebagian terdiri dari hutan rawa.

Hutan rawa gambut merupakan suatu ekosistem yang unik dan di dalamnya terdapat beranekaragam flora dan fauna. Keanekaragaman flora yang ada di hutan gambut salah satunya adalah jenis anggrek. Meskipun demikian, hutan rawa gambut adalah suatu ekosistem yang rapuh, sehingga rentan terhadap gangguan dan sulit mengembalikan ke kondisi awal (Syaufina et al. 2004). Jenis anggrek di kawasan hutan rawa gambut merupakan kekayaan alam hayati yang perlu diungkapkan sebagai daya dukung kawasan tersebut, sekaligus akan menunjang kegiatan penelitian, pengembangan kawasan, dan pelestarian sumber daya alam.

Pengumpulan data keanekaragaman anggrek di Kabupaten Belitung, khususnya di hutan rawa gambut Kabupaten Belitung belum pernah dilaku- 
kan. Mengingat hal tersebut, maka perlu sekali dilakukan penelitian inventarisasi jenis-jenis anggrek di hutan rawa gambut. Penelitian ini bertujuan untuk mengidentifikasi jenis-jenis anggrek alam yang ada di hutan rawa gambut Kabupaten Belitung guna melengkapi data jenis anggrek yang ada di Indonesia.

\section{BAHAN DAN METODE}

\section{Waktu dan Tempat Penelitian}

Penelitian ini dilakukan pada bulan Maret 2017 di hutan rawa gambut Kabupaten Belitung yaitu di Desa Juru Sebrang, Desa Perawas dan Dusun Mempiuk, Desa Cerucuk (Gambar 1). Identifikasi jenis-jenis anggrek yang dikoleksi dilakukan di Herbarium Bangka Belitungense dan Herbarium Bogoriense (BO), Pusat Penelitian BiologiLIPI, Cibinong.

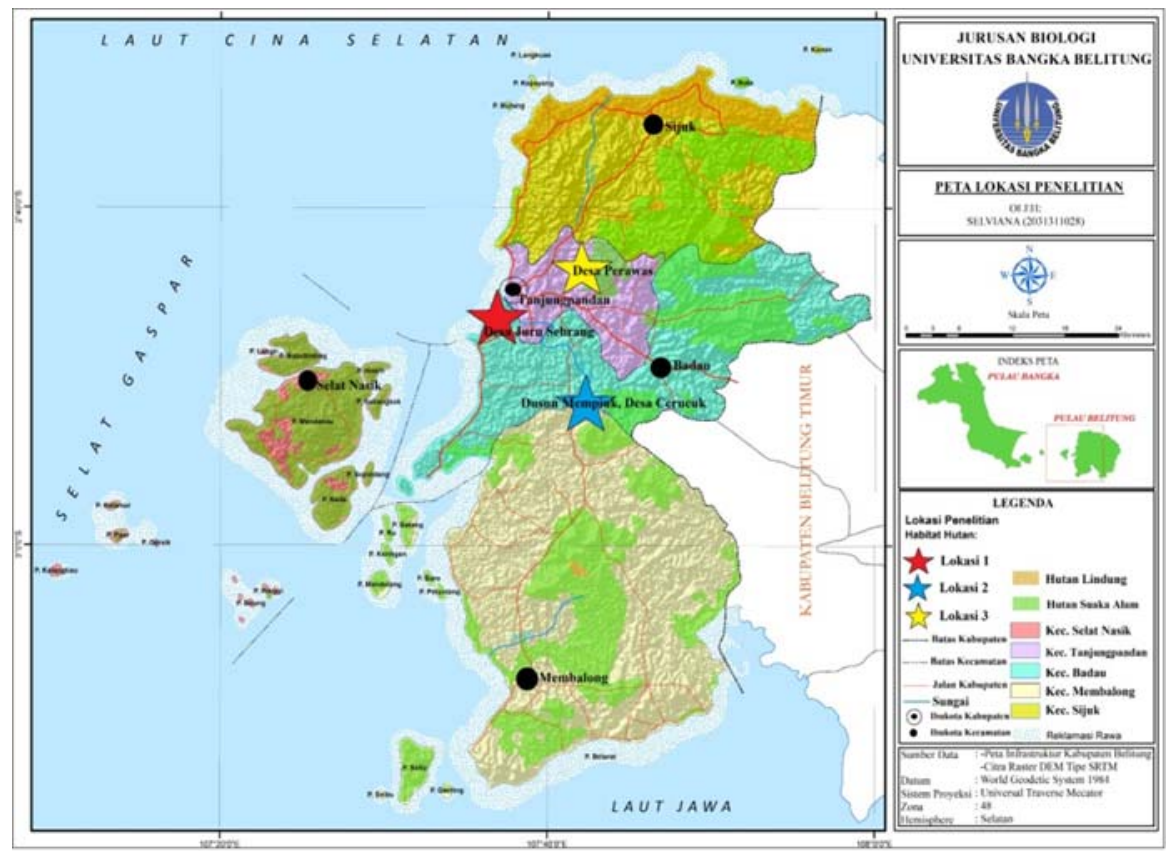

Gambar 1. Peta lokasi pengambilan sampel anggrek di hutan rawa gambut Kabupaten Belitung.

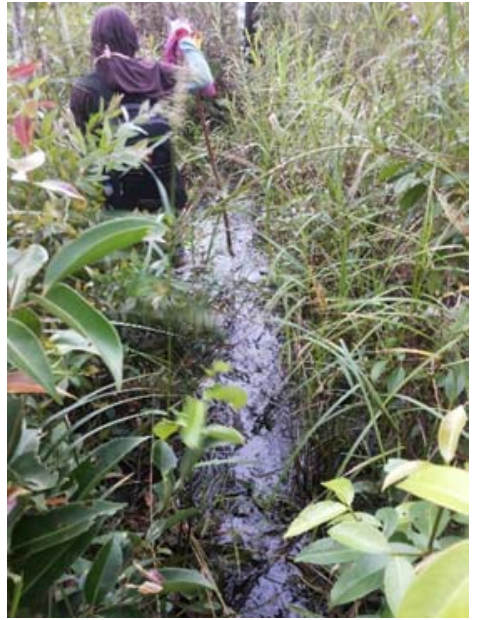

Lokasi 1

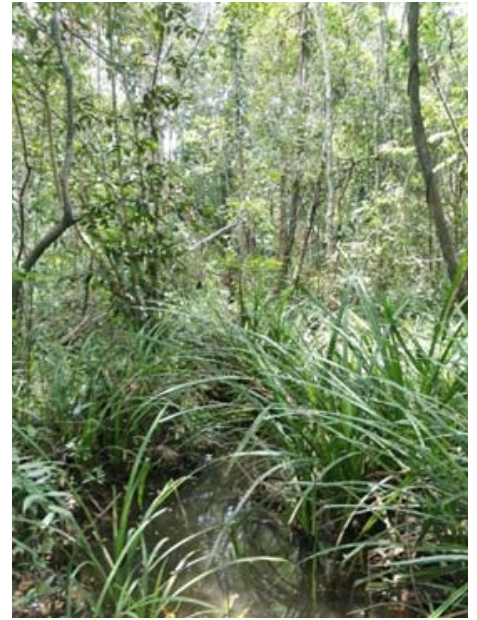

Lokasi 2

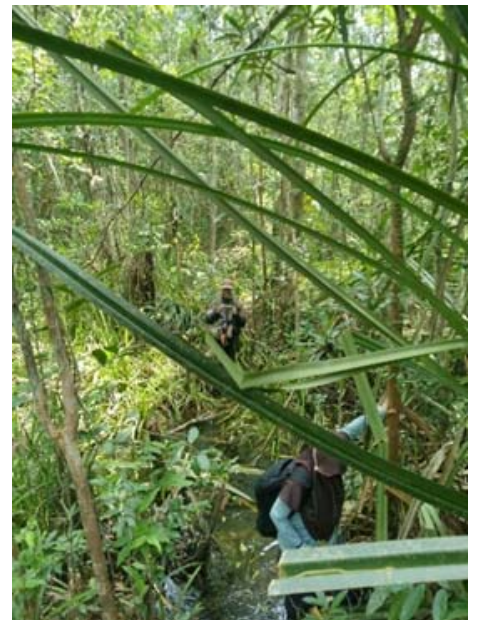

Lokasi 3

\section{Cara Kerja}

Penelitian ini dilakukan dengan metode eksplorasi (jelajah) dan pengumpulan data taksonomi (Rugayah et al. 2004), teknik jelajah dengan cara berjalan menjelajahi lokasi dalam suatu wilayah yang terdapat anggrek. Kemudian mencatat setiap jenis anggrek yang ditemukan di lapang dan mengambil sampel anggrek kemudian disemprot de- 
ngan alkohol 70\% serta membuat dokumentasi dari masing-masing anggrek yang ditemukan.

Data lapangan seperti koordinat, ketinggian lokasi, suhu udara, kelembaban, intensitas cahaya dan $\mathrm{pH}$ tanah dikumpulkan di lokasi penelitian. Spesimen herbarium yang dikoleksi dipreservasi dalam alkohol 70\%. Spesimen herbarium yang berbunga dikoleksi dan diproses lebih lanjut di Herbarium Bangka Belitung yang kemudian dilanjutkan dengan pencarian studi pustaka untuk mengetahui identitas dari jenis-jenis anggrek yang dikumpulkan dan disimpan di herbarium Bangka Belitungense Universitas Bangka Belitung. Jenis-jenis yang tidak dapat teridentifikasi di herbarium Bangka Belitungense Universitas Bangka Belitung, dilanjutkan proses identifikasi di Herbarium Bogoriense, LIPI Cibinong.

\section{HASIL DAN PEMBAHASAN}

Berdasarkan penelitian yang dilakukan di ketiga lokasi hutan rawa gambut, Kabupaten Belitung ditemukan 9 jenis anggrek dari 6 marga, terlihat pada Tabel 1, sedangkan kondisi faktor lingkungan di ketiga lokasi dapat dilihat pada Tabel 2.

Tabel 1. Jenis-jenis anggrek yang ditemukan di hutan rawa gambut Kabupaten Belitung

\begin{tabular}{lllllc}
\hline \multirow{2}{*}{ Marga } & & \multicolumn{1}{c}{ Spesies } & Lokasi \\
\cline { 3 - 5 } & & & Habitat & L1 & L2 L3 \\
\hline Bromheadia Lindl. & Bromheadia finlaysoniana (Lindl.) Miq. & Terestrial & + & + & + \\
Bulbophyllum Thouv. & Bulbophyllum macranthum Lindl. & Epifit & - & - & + \\
& Bulbophyllum patens King ex Hook.f. & Epifit & - & - & + \\
Dendrobium Sw. & Dendrobium crumenatum Sw. & Epifit & - & - & + \\
& Dendrobium lamellatum (Blume) Lindl. & Epifit & - & - & + \\
Plocoglottis Blume & Plocoglottis lowii Rchb.f. & Terestrial & + & + & + \\
& Plocoglottis plicata (Roxb.) Ormerod. & Terestrial & + & + & + \\
Thecopus Seidenf. & Thecopus secunda (Ridl.) Seidenf. & Epifit & - & + & - \\
Thrixspermum Blume & Thrixspermum acuminatissimum (Bllume) Rchb.f. & Epifit & - & - \\
\hline
\end{tabular}

Ket; L= Lokasi, $(+)$ = ditemukan, $(-)$ = tidak ditemukan

Tabel 2. Faktor lingkungan di ketiga lokasi hutan rawa gambut Kabupaten Belitung

\begin{tabular}{clccc}
\hline \multirow{2}{*}{ No } & \multirow{2}{*}{ Parameter Pengukur } & \multicolumn{3}{c}{ Lokasi } \\
\cline { 3 - 5 } & & L1 & L2 & L3 \\
\hline 1 & Suhu Udara $\left({ }^{\circ} \mathrm{C}\right)$ & 28 & 28 & 31 \\
2 & Kelembaban Udara (\%) & 85 & 89 & 75 \\
3 & Intensitas Cahaya (lux) & 500 & 300 & 500 \\
4 & pH Tanah & 4,5 & 4,5 & 5,5 \\
\hline
\end{tabular}

Kunci determinasi marga anggrek di hutan rawa gambut Kabupaten Belitung

1. a. Pertumbuhan monopodial Thrixspermum

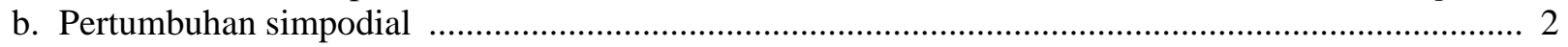

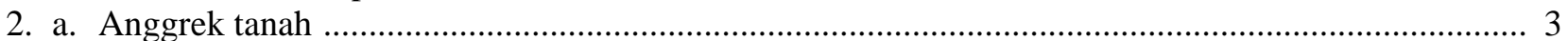

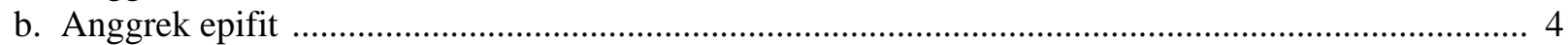


3. a. Berumbi semu, daging daun tipis, ujung daun melancip Plocoglottis

b. Tidak berumbi semu, daging daun tebal, ujung daun membelah Bromheadia

4. a. Perbungaan muncul dari ujung batang atau umbi semu Dendrobium

b. Perbungaan muncul dari pangkal umbi semu Bulbophyllum

5. a. Batang atau umbi semu beruas-ruas Thecopus

Hasil penelitian jenis-jenis anggrek di hutan rawa gambut Kabupaten Belitung berhasil ditemukan 9 jenis anggrek dari 6 marga, yaitu 6 jenis anggrek epifit dan 3 jenis anggrek terestrial seperti yang tampak pada Tabel 1. Hasil dalam tabel menunjukkan bahwa jumlah jenis anggrek yang berhasil ditemukan di ketiga lokasi berbeda-beda, 3 jenis anggrek pada lokasi 1, 4 jenis di lokasi 2 dan 8 jenis pada lokasi 3. Dari ketiga lokasi tersebut jenis anggrek yang paling banyak terdapat pada lokasi 3 dikarenakan pada lokasi tersebut faktor lingkungan lebih mendukung untuk pertumbuhan anggrek terlihat pada Tabel 2. Sesuai dengan pendapat Hasanuddin (2010), bahwa kawasan yang memiliki kelembaban yang tinggi dan suhu yang relatif rendah sangat memungkinkan tumbuhan anggrek dapat tumbuh dan berkembang sangat baik.

Pada umumnya jenis anggrek yang ada di Sumatra tidak jauh berbeda dengan jenis anggrek yang ditemukan di Bangka Belitung (Comber 2001). Dari beberapa jenis anggrek yang ditemukan, terdapat satu jenis anggrek yaitu Thecopus secunda yang persebarannya di Indonesia hanya ada di Kalimantan, sehingga anggrek ini merupakan rekaman baru untuk anggrek Sumatra khususnya di Belitung. Menurut Handoyo (2010) persebaran anggrek $T$. secunda hanya ada di Kalimantan dan Semenanjung Malaya. Wood et al. (1993), Seidenfaden \& Wood (1992) juga menyatakan bahwa persebaran anggrek $T$. secunda terdapat di Kalimantan, Sabah, Sarawak dan Semenanjung Malaya. Hasil identifikasi dari buku Comber 2001, Orchids of Sumatra, anggrek ini juga tidak ditemukan.

Menurut Nursub'i et al. (2011) anggrek T. secunda merupakan salah satu anggrek yang sudah jarang ditemukan dan sangat menarik. Keberadaan anggrek $T$. secunda di Pulau Belitung perlu mendapat perhatian khusus karena menurut Nursub'i et al. (2011) anggrek ini merupakan salah satu anggrek endemik di Kalimantan. Namun dari hasil identifikasi ternyata $T$ secunda bukan hanya tersebar di Kalimantan. Distribusi jenis ini di Indonesia ternyata lebih luas dari yang pada awalnya diinformasikan. Dressler (1981) dan Arditti (1992) men- duga bahwa penyebaran anggrek yang mencapai jarak sangat jauh kemungkinan karena terbawa oleh angin. Berdasarkan informasi tersebut dimungkinan hal yang sama terjadi pada anggrek $T$. secunda, namun Ridley (1930) juga menyatakan bahwa ada sebagian biji anggrek yang dapat dipencarkan melewati laut pada umunya hanya dapat mencapai daerah dataran rendah, sedangkan di Kabupaten Belitung sendiri anggrek $T$. secunda di temukan di hutan rawa gambut dengan ketinggian $37 \mathrm{~m}$ dpl. Dengan demikian diduga anggrek ini dipencarkan melewati laut. Untuk lebih mengetahui pastinya diperlukan penelitian lebih lanjut.

Sebagian besar anggrek yang ditemukan adalah jenis angrek epifit. Banyaknya jenis anggrek epifit yang ditemukan di lokasi ini dikarenakan jumlah jenis anggrek epifit lebih banyak dibandingkan anggrek terestrial dan litofit. Gravendeel et al. (2004), mengatakan bahwa lebih dari $70 \%$ jenis anggrek yang tumbuh adalah jenis anggrek epifit. Selain itu, karena disebabkan kondisi terestrial di rawa gambut yang cenderung asam sehingga kurang mendukung untuk pertumbuhan anggrek.

Dressler (1990) menyebutkan salah satu perbedaan cara hidup antara jenis anggrek epifit dan anggrek terestrial adalah kebutuhan cahaya matahari. Tirta et al. (2010), juga menyatakan kehidupan jenis anggrek epifit dipengaruhi oleh intensitas cahaya matahari, sifat hidupnya yang menempel pada tumbuhan lain (epifit) merupakan salah satu cara beradaptasi untuk mendapatkan cahaya matahari karena jenis epifit membutuhkan intensitas cahaya yang lebih tinggi.

Jenis yang paling banyak dijumpai di lokasi penelitian adalah dari marga Bulbophyllum Thou., Dendrobium Sw. dan Plocoglottis Blume. Menurut Comber (2001) marga Bulbophyllum dan Dendrobium merupakan marga anggrek yang mempunyai keanekaragaman jenis terbanyak di kawasan Malesia. Dressler (1993), menyatakan anggrek Bulbophyllum di dunia sekitar 1000 jenis dan Dendrobium 900 jenis. Pulau Sumatra memiliki anggrek sekitar 136 jenis Bulbophyllum dan 116 jenis Dendrobium (Comber 2001). 
Kunci indentifikasi jenis anggrek di hutan rawa gambut Kabupaten Belitung

Bulbophyllum Thouv.

1. a. Rimpang mendukung umbi semu dengan jarak $5-8 \mathrm{~cm}$, ukuran daun $15,6-19 \times 5,8-6,8 \mathrm{~cm}$

Bulbophyllum patens

b. Rimpang mendukung umbi semu dengan jarak 2,5-4 cm, ukuran daun $10,5-15$ x 2,8-4 cm Bulbophyllum macranthum

Dendrobium Sw.

1. a. Umbi semu pipih, daun terdapat pada ujung umbi semu Dendrobium lamellatum

b. Umbi semu silinder, daun terletak berseling pada batang Dendrobium crumenatum

\section{Plocoglottis Blume}

1. a. Daun ungu muda bagian atas, ungu tua bagian bawah, rakis ungu, umbi semu mengerucut Plocoglottis lowii

b. Daun hijau, rakis hijau,umbi semu menggalah Plocoglottis plicata

\section{Deskripsi}

Berikut deskripsi singkat jenis anggrek yang ditemukan berdasarkan pengamatan di lapangan, spesimen yang diamati, informasi daerah sebaran mengikuti Comber (2001), Wood et al. (1993), Seidenfaden \& Wood (1992) dan Handoyo (2010), dan catatan penting dari masing-masing jenis yang ditemukan di hutan rawa gambut di Kabupaten Belitung.

\section{Bromheadia finlaysoniana (Lindl.) Miq.}

Anggrek terestrial, simpodial, tumbuh bergerombol. Batang: kecil, bulat, tegak ke atas, keras, berwarna hijau ada juga yang ungu. Daun: berwarna hijau, melonjong, panjang 7-9 cm, lebar 1,8 $-2 \mathrm{~cm}$, berseling, liat, lebih kecil ke arah pangkal dan ujung daun, ujung membelah sama rata. Perbungaan muncul dari ujung batang, rakis zig zag. Bunga: berwarna putih; berukuran sekitar $7 \mathrm{~cm}$ panjangnya, bibir bercuping 3, cuping samping berurat ungu, cuping tengah mempunyai lunas berwarna kuning; tugu berwarna putih (Gambar 2 A).

Spesimen yang diamati: Sumatra: Bangka Belitung, Desa Juru Sebrang (Kec. Tanjungpandan), 19 Maret 2017, Selviana, Sv.16; Desa Mempiuk (Kec. Badau), 25 Maret 2017, Selviana, Sv.36 dan Desa Perawas (Kec. Tanjungpandan), 26 Maret 2017, Selviana, Sv.46; Padang. P. Bangka, Ne Belinyu, Maret 1983, Dr. Tony Whitters, AJWP 11; Unggas Mandi Hill, B Halawang, Bohorok, 03 November 1980, H. Wiriadinata \& Maskuri, 633.

Tumbuh di tanah dengan genangan air dan naungan yang tertutup, pada ketinggian 16-37 m dpl.

Persebaran: Australia, Brunei, Burma, Indochina, Indonesia (Sumatra, Jawa, Kalimantan, Maluku), New Guinea, Sabah, Semenanjung Malaya, Serawak, Thailand dan Vietnam.
Catatan: Anggrek ini sekilas mirip dengan marga Epidendrum.

Bulbophyllum macranthum Lindl.

Anggrek epifit, simpodial; rimpang menjalar dan bercabang-cabang, sangat tebal, berserabut, seluruh permukaan rimpang tertutup oleh akar, diameter rimpang $6 \mathrm{~mm}$. Batang: berumbi semu, beruas-ruas, membulat telur, panjang 1,5-2,4 cm, diameter 0,6-1 cm, setiap umbi semu menompang satu helai daun, jarak antar umbi semu 2,5-4 cm. Daun: berwarna hijau, melonjong, panjang 10,5-15 $\mathrm{cm}$, lebar 2,8-4 cm, tebal dan berdaging, tepi rata, ujung daun tumpul.

Comber (2001) mendeskripsikan bahwa perbungaan muncul dari rimpang, menompang satu bunga. Bunga berukuran 5,5 cm, tidak menyungsang (non resupinate), berwarna putih berkilau dengan bercak merah; kelopak punggung melonjong, lancip, biasanya bunga melengkung ke bawah, panjang $3 \mathrm{~cm}$; kelopak samping tegak, menyegitiga bundar telur, panjangnya sama tetapi melengkung ke dalam dan lebih menyempit, permukaan dalam kuning atau putih kehijauan; mahkota terulur, melonjong-melanset, lancip; bibir kecil, menyegitiga, melengkung, berdaging, panjang $5 \mathrm{~mm}$, cuping samping kecil dan membundar, cuping tengah melonjong, menumpul (Gambar 2 B).

Spesimen yang diamati: Sumatra: Bangka Belitung, Desa Perawas (Kec Tanjungpandan), 26 Maret 2017, Selviana, Sv.47; Jawa: P. Karimunjawa, Maret 1931, Karta, 290.

Tumbuh menempel pada pohon yang berkulit tebal licin dengan naungan yang cukup tertutup dengan ketinggian sekitar $2 \mathrm{~m}$.

Persebaran: Brunei, Burma, Filipina, Indochina, Indonesia (Jawa, Kalimantan, Maluku, Sulawesi, Sumatra), New Guinea, Sabah, Sarawak, 
Semenanjung Malaya, Thailand dan Vietnam.

Catatan: Ketika ditemukan di lapangan anggrek ini belum berbunga.

\section{Bulbophyllum patens King ex Hook.f.}

Anggrek epifit, simpodial; rimpang menjalar dan bercabang, berserabut, seluruh permukaan tertutup oleh akar, diameter rimpang $7 \mathrm{~mm}$. Batang: berumbi semu,beruas-ruas, membulat telur memanjang, panjang umbi semu $2,3-3 \mathrm{~cm}$, diameter 2 $-2,3 \mathrm{~cm}$, setiap umbi semu menompang satu helai daun, jarak antar umbi semu 5-8 cm. Daun: berwarna hijau, melonjong, panjang 15,6-19 cm, lebar 5,8-6,8 cm, tebal dan berdaging, tepi rata, ujung daun membulat, membelah sama rata. Perbungaan menompang satu bunga, panjang gagang perbungaan $4 \mathrm{~cm}$. Bunga: tidak menyungsang, membuka lebar, berwarna keputihan denngan bintik-bintik merah kekuningan. kelopak punggung melonjong, tumpul dan menebal di bagian ujung, melengkung di bagian atas tugu; kelopak samping membulan sabit (melancor) lancip, bagian pangkal lebih lebar; mahkota melanset, lancip; bibir tumpul, sedikit melengkung terbalik dan tersalur di dekat bagian pangkal, tebal dan berdaging; tugu menyegitiga (Gambar 2 C).

Spesimen yang diamati: Sumatra: Bangka Belitung, Desa Perawas (Kec Tanjungpandan), 26 Maret 2017, Selviana, Sv.55; Bt. Badak, LayangLayang, 28 Januari 1959, Hassan \& Kadim, H. 101; Kalimantan: Wanariset, Balikpapan, East Kalimantan (Borneo), 3 Oktober 1979, J.J. Afriastini, $154 \mathrm{~A}$.

Tumbuh menempel pada pohon yang berkulit tebal dengan menjalar di batang pohon dengan ketinggian $1 \mathrm{~m}$, di area yang cukup terbuka.

Persebaran: Brunei, Indonesia (Kalimantan dan Sumatra), Sabah, Semenanjung Malaya dan Thailand.

Catatan: Dilihat dari bentuk daunnya hampir sama dengan anggrek B.macranthum, hanya saja ukuran daunnya lebih besar B.patens.

\section{Dendrobium crumenatum Sw.}

Anggrek epifit, terkadang ditemukan litofit, simpodial; tumbuh bergerombol. Umbi semu: beruas-ruas, panjang umbi semu $3-8 \mathrm{~cm}$, diameter 1,2-2 cm. Batang: tumbuh dari ujung umbi semu, panjang, kadang tumbuh tunas baru pada bagian batang yang bercabang, setiap batang terdapat 816 daun. Daun: berwarna hijau, melonjong-melanset, panjang 4-6 cm, lebar 1,5-2 cm, menempel pada batang, berseling, tepi rata, ujung tumpul, membelah sama rata. Perbungaan muncul dari ujung batang, setiap tangkai terdapat 3-8 kuntum bunga. Bunga: berwarna putih, berukuran $5 \mathrm{~cm}$, kelopak menyegitiga, ujung runcing, mahkota melanset, lebih pendek dari kelopak; bibir bunga bercuping tiga, cuping samping lurus, tidak bulat, cuping tengah lebih lebar, tepi bergelombang, ujung membulat, terdapat warna kuning di bagian tengah bibir (Gambar 2 D).

Spesimen yang diamati: Indonesia: Sumatra: Bangka Belitung, Desa Perawas (Kec. Tanjungpandan), 26 Maret 2017, Selviana, Sv.49; Filipina: Polillo, Oktober-November 1909, R. C. Megregor, 10459; Camiguin Island, Babuyan, Juni-Juli 1907, Bugenio Felix, 4085.

Tumbuh menempel pada pohon yang berbatang besar dan berkulit tebal, dan ada juga yang tumbuh di bebatuan di area yang terbuka.

Persebaran: China, Filipina, India, Indonesia (Jawa, Kalimantan, Kepulauan Sunda Kecil, Maluku, Sulawesi, dan Sumatra), Indochina, New Guinea, Sabah, Sarawak, dan Semenanjung Malaya.

Catatan: Berbunga penuh hanya untuk satu hari, kemudian menutup kembali pada sore hari. Column (tugu) bagian atas dari anggrek D. crumenatum mirip seperti kepala dan leher burung merpati, sementara sepal dan kelopaknya menyerupai sayap dan ekor burung. Sehingga sebagian masyarakat menyebutnya “ anggrek merpati ”. Sedangkan harum seperti bau bunga melati.

Dendrobium Iamellatum (Blume) Lindl.

Anggrek epifit, simpodial; tumbuh bergerombol ada juga yang tunggal. Batang: umbi semu berbentuk pipih, beruas-ruas, panjang 3,5-4,5 cm, lebar 1,3-2 cm, setiap umbi semu menompang 2 daun. Daun: berwarna hijau, muncul dari ujung umbi semu, melanset, panjang 7-10 cm, lebar 1,3$3,3 \mathrm{~cm}$, tepi rata, ujung meruncing. Perbungaan muncul dari dekat tangkai daun, di ujung umbi semu. Bunga: berukuran 2,2 cm, berwarna putih kekuningan kebanyakan kuning pucat, terkadang berwarna hijau di bagian kelopak; kelopak punggung membundar telur, melancip; kelopak samping lebih lebar; mahkota melonjong-menyudip; bibir bagian dalam berwarna kuning (Gambar $2 \mathrm{E}$ ).

Spesimen yang diamati: Sumatra: Bangka Belitung, Desa Perawas (Kec. Tanjungpandan), 26 Maret 2017, Selviana, Sv.48.

Tumbuh menempel pada pohon yang berkulit tebal di area cukup ternaungi.

Persebaran: Burma, Indonesia (Jawa, Kalimantan dan Sumatra), Malaysia, Sabah, Sarawak, Semenanjung Malaya dan Thailand. 
Catatan: ukuran umbi semu lebih besar dari ukuran bunganya dan bentuk bunganya sekilas mirip seperti terompet.

\section{Plocoglottis lowii Rchb.f.}

Anggrek terestrial, simpodial; tumbuh bergerombol ada juga yang tunggal, rimpang pendek. Batang: berumbi semu, mengerucut, setiap umbi semu menompang satu helai daun, berwarna kuning langsat dan ungu, panjang 2,2-5,5 cm. Daun: berwarna ungu muda bagian atas, ungu tua bagian bawah, daun melanset, panjang 9-2,5 cm, lebar 2,3 $-7 \mathrm{~cm}$, berlipat, tipis, tepi rata, ujung melancip, menyempit ke arah pangkal, panjang tangkai daun 3,5 cm. Perbungaan muncul dari pangkal umbi semu, tegak keatas, berbulu, rakis berwarna ungu, panjang $70 \mathrm{~cm}$. Bunga: kecil, berukuran sekitar 3 $\mathrm{cm}$, kelopak dan mahkota kuning; bibir merah, menggulung; tugu kuning (Gambar $2 \mathrm{~F}$ ).

Spesimen yang diamati: Sumatra: Bangka Belitung, Desa Juru Sebrang (Kec. Tanjungpandan), 19 Maret 2017, Selviana, Sv.18; Desa Mempiuk (Kec. Badau), 25 Maret 2017, Selviana, Sv.37 dan Desa Perawas (Kec. Tanjungpandan), 26 Maret 2017, Selviana, Sv.52.

Tumbuh di tanah dengan tertutup serasah dedaunan di area yang tertutup dengan naungan yang rapat.

Persebaran: Indonesia (Kalimantan, Maluku dan Sumatra), New Guinea, Pulau Andaman, Sabah, Sarawak, Semenanjung Malaya dan Thailand.

Catatan: Bunganya sangat mirip dengan $P$. quadrifolia, tetapi spesies ini memiliki beberapa daun di setiap umbi semu, sementara $P$. lowii hanya memiliki satu.

\section{Plocoglottis plicata (Roxb.) Ormerod}

Anggrek terestrial, simpodia; tumbuh bergerombol ada juga yang tunggal, rimpang bercabang, berdaging. Batang: berumbi semu, menompang satu helai daun, berwarna hijau muda, panjang 3,5-4 cm. Daun: melonjong-memanjang, panjang 16,4-21,6 cm dan lebar 3,9-5,9 cm, berlipat, tipis, tepi rata, ujung lancip, menyempit kearah pangkal, berwarna hijau muda, panjang tangkai daun 3,5-4,5 cm. Perbungaan muncul dari pangkal umbi semu, tegak ke atas, berbulu, rakis berwarna hijau.

Menurut Comber (2001) perbungaan satu atau dua, panjang gagang perbungaan $15-30 \mathrm{~cm}$, mendukung 10-12 bunga. Bunga membuka lebar, berukuran $3 \mathrm{~cm}$, berwarna kuning bercampur merah, kelopak dan mahkota melanset, ujung lancip (Gambar 2 G).
Spesimen yang diamati: Sumatra: Bangka Belitung, Desa Juru Sebrang (Kec. Tanjungpandan), 19 Maret 2017, Selviana, Sv.17; Desa Mempiuk (Kec. Badau), 25 Maret 2017, Selviana, Sv.38 dan Desa Perawas (Kec. Tanjungpandan), 26 Maret 2017, Selviana, Sv.51.

Tumbuh di tanah dengan tertutup serasah dedaunan di area yang tertutup dengan naungan yang rapat.

Persebaran: Filipina, Indonesia (Jawa Kalimantan, Maluku, Sulawesi, dan Sumatra), dan Semenanjung Malaya.

Catatan: Kebanyakan anggrek ini ditemukan hidup di daerah yang lembab dan biasanya ketika di lapangan kalau ada anggrek $P$. plicata selalu ada anggrek $P$. lowii.

\section{Thecopus secunda (Ridl.) Seidenf.}

Anggrek epifit, simpodial; tumbuh bergerombol. Batang: berumbi semu, tidak beruas-ruas, membulat telur memanjang, mengkerut, menompang 1-2 daun, panjang umbi 3,5-4,5 cm, lebar 1 $\mathrm{cm}$. Daun: melonjong memanjang, panjang 11-23 cm lebar 1,5-2,3 cm, daun tipis, tepi rata, ujung meruncing, menyempit di bagian pangkal daun, panjang tangkai daun $2,5-3 \mathrm{~cm}$. Perbungaan muncul dari pangkal umbi semu, panjang gagang perbungaan $\pm 15 \mathrm{~cm}$, bercabang, menompang 6-15 kuntum bunga, menjuntai ke bawah. Bunga: mekar bersamaan, warna hijau dengan garis cokelat pada kelopak dan mahkota, kelopak lebih besar dari pada mahkota, berbentuk membundar telut, ujung meruncing; kelopak samping melengkung keluar; kelopak punggung melengkung kedalam; mahkota lonjong, meruncing, ukuran lebih kecil dari kelopak, melengkung kedalam; bibir bunga berwarna putih bercak keunguan, menyegitiga (Gambar 2 $\mathrm{H})$.

Spesimen yang diamati: Bangka Belitung, Desa Mempiuk (Kec. Badau), 25 Maret 2017, Selviana, Sv.35.

Anggrek T. secunda ditemukan tumbuh menempel pada pohon dengan ketinggian kurang lebih $1 \mathrm{~m}$, berkulit tebal, di area yang terbuka dengan intensitas yang cukup. Tumbuh di hutan rawa dengan ketinggian 16-37 m dpl.

Persebaran: Indonesia (Kalimantan), Sabah, Sarawak dan Semenanjung Malaya. Koleksi dari Belitung ini merupakan rekaman baru untuk anggrek Sumatra.

Catatan: Anggrek ini merupakan rekaman baru untuk Sumatra khususnya di Belitung. 
Thrixspermum acuminatissimum (Blume) Rchb.f. Anggrek epifit, monopodial; hidup tunggal. Batang: berumbi semu sangat pendek, lurus, menompang 3-6 helai daun. Daun: berwarna hijau, berseling, melanset, panjang 8,2-10,6 cm, lebar 1,3 $-1,8 \mathrm{~cm}$, tebal, tepi rata, ujung meruncing. Perbungaan muncul dari pangkal batang, rakis membentuk zig zag, panjang 5-10 cm.

Menurut Comber (2001) bunga membuka satu (jarang dua) dalam suatu waktu, kelopak kuning, bibir putih dengan bercak cokelat; kelopak memita, panjang $3 \mathrm{~cm}$, lebar $1,5 \mathrm{~mm}$, luas di bagian pangkal, sempit di bagian ujung, panjang mahkota 2,5 cm, lebih sempit dari kelopak, menyegitiga tidak beraturan, bagian tepinya atau cuping samping pendek dan bulat, panjang cuping tengah $1,5 \mathrm{~cm}$, membenang di bagian ujung (Gambar 2 I).

Spesimen yang diamati: Sumatra: Bangka Belitung, Desa Perawas (Kec. Tanjungpandan), 26 Maret 2017, Selviana, Sv.30.

Tumbuh menempel pada pohon yang berkulit tebal di area tertutup dengan naungan yang rapat, dengan kisaran ketinggian 1,5-25 m.

Persebaran: Filipina, Indonesia (Jawa, Kalimantan dan Sumatra), Kamboja, Sabah, Sarawak, Semenanjung Malaya, Singapura dan Thailand.

Catatan: Ketika di temukan di lapangan anggrek ini sudah selesai berbunga.

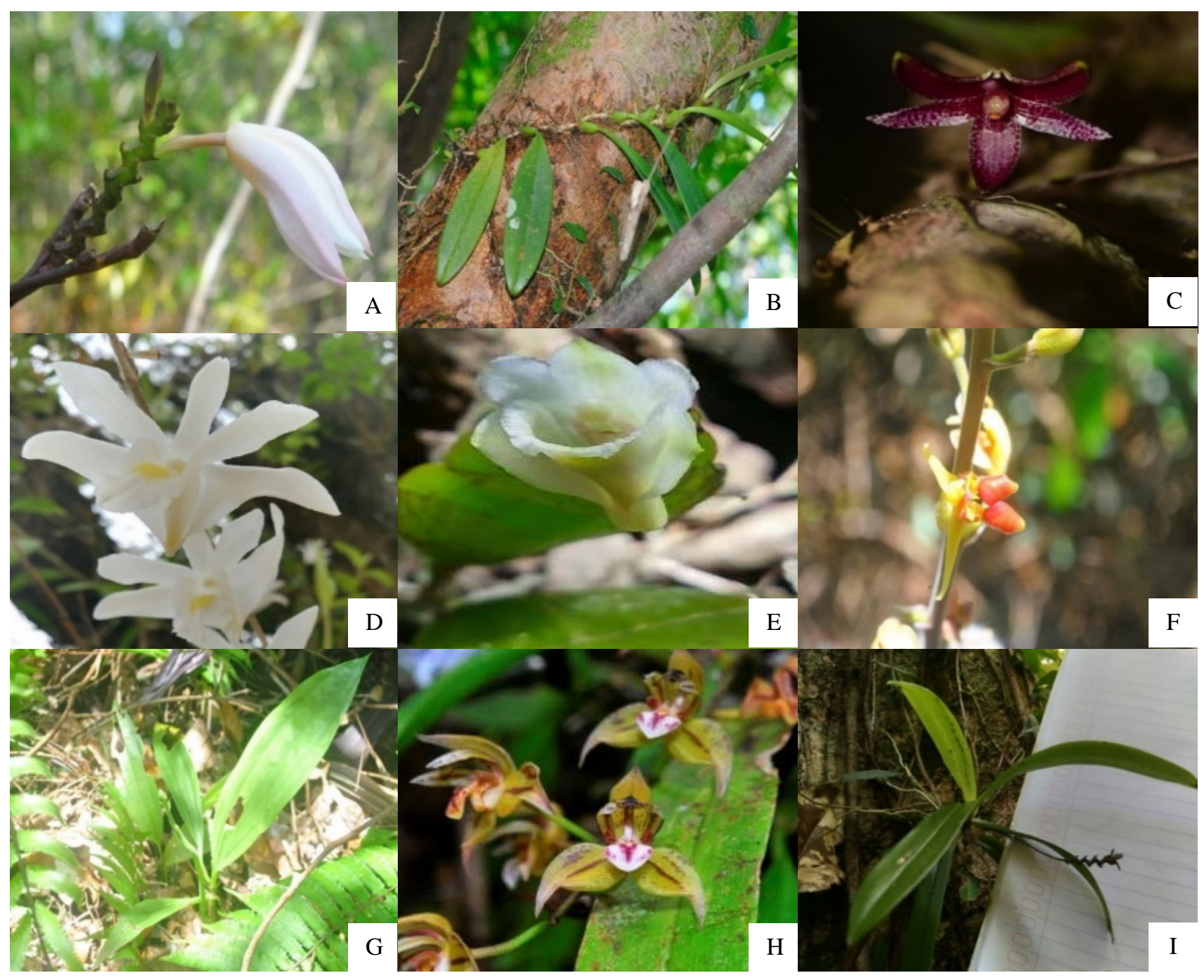

Gambar 2. A. Bromheadia finlaysoniana (Lindl) Miq., B. Bulbophyllum macrantum Lindl., C. BulbophyIlum patens King x Hook.f., D. Dendrobium crumenatum Sw., E. Dendrobium lamellatum (Bl.) Lindl., F. Plocoglottis lowii Rchb.f., G. Plocoglottis plicata (Roxb.), H. Thecopus secunda (Ridl.) Seidenf, I. Thrixspermum acuminatissimum (Bl.) Rchb.f. 


\section{KESIMPULAN}

Berdasarkan hasil penelitian yang telah dilakukan di hutan rawa gambut Kabupaten Belitung dapat disimpulkan bahwa terdapat 9 jenis anggrek (6 jenis anggrek epifit dan 3 jenis anggrek terestrial) dari 6 marga. Terdapat satu jenis anggrek rekaman baru yaitu Thecopus secunda.

\section{UCAPAN TERIMA KASIH}

Penulis mengucapkan banyak terima kasih kepada Ibu Nur Annis Hidayati, S.Si., M.Sc. selaku ketua Jurusan Biologi. Ucapan terima kasih juga penulis sampaikan kepada semua dosen Biologi Universitas Bangka Belitung, Dinas Kehutanan Kabupaten Belitung, masyarakat Kabupaten Belitung serta Biodiversity Observer Belitung yang sudah banyak membantu selama penelitian di lapangan. Terima kasih juga disampaikan kepada Herbarium Bangka Belitungense dan Herbarium Bogoriense (BO) yang telah memberikan kesempatan kepada penulis untuk memeriksa spesimen anggrek. Pihak perpustakaan LIPI dan FPPB UBB, serta semua pihak yang sudah berkontribusi dalam kegiatan ini dan tidak memungkinkan disebutkan satu per satu.

\section{DAFTAR PUSTAKA}

Agustin D \& Widowati H. 2015. Inventarisasi Keanekaragaman Anggrek (Orchidaceae) di Hutan Resort Way Kanan Balai Aman Nasional Way Kambas Sebagai Sumber Informasi dalam Melestarikan Plasma Nutfah. BIOEDUKASI Jurnal Pendidikan Biologi Universitas Muhammadiyah Metro 6(1): 3846.

Arditti J. 1992. Fundamentals of Orchid Biology. John Wiley and Sons. New York. Pp 704.

Comber JB. 2001. Orchid of Sumatra. The Royal Botanic Garden Kew. London. Pp: 1036.

Dressler RI. 1981. The Orchids Natural History and Clasifications. Harvard University Press. London.

Dressler RI. 1990. The Orchids Natural History and Clasifications. Harvard University Press. London.

Dressler RI. 1993. Phylogeny and Classifications on the Orchid Family. Cambridge University Press. North America.
Gravendeel B, Smithson A, Slik FJW \& Schuiteman A. 2004. Epiphytism and pollinator specialization: drivers for orchid diversity? Phil. Trans. R. Soc. London 359: 15231535.

Handoyo F. 2010. Orchids Of Indonesia. Perhimpunan Anggrek Indonesia. Jakarta. Pp: 325.

Indarto N. 2011. Pesona Anggrek Petunjuk Praktis Budidaya Dan Bisnis Anggrek. Penerbit Cahaya Atma. Yogyakarta. Pp: 110.

Lestari DA \& Santoso W. 2011. Inventory and Habitat Study of Orchids species in Lamedai Nature Reserve, Kolaka, Southeast Sulawesi. Biodiversitas 12(1): 28-33.

Nursub'i. Panggabean I BR, Abduh M, Joharuddin D, Setiawan R \& Helmi M. 2011. Keanekaragaman Hayati Jenis Anggrek Taman Nasional Bukit Baka Bukit Raya. Sintang: Balai TNBBBR. Pp: 85.

Ridley HN. 1930. The Dispersal of Plants Throughout the World. L.Reeve : Ashford, Kent.

Rugayah, Retnowati A, Windadri FI \& Hidayat A. 2004. Pengumpulan Data Taksonomi. Dalam: Rugayah, Widjaja EA \& Praptiwi (eds.). Pedoman Pengumpulan Data Keanekaragaman Flora. Bogor: Puslit-LIPI.pp. 542.

Syaufina L, Nurudin AA, Basharuddin J, See LF \& Yuso FMRM. 2004. The Effects of Climatic Variations on Peat Swamp Forest Condition and Peat Combustibility. Jurnal Manajemen Hutan Tropika X (1): 1-14

Seidenfaden G \& Wood JJ. 1992. The Orchids of Peninsular Malaysia and Singapore. Fredensborg. Denmark. Pp: 779.

Tirta IG, Lugrayasa IN \& Irawati. 2010, Studi Anggrek Epifit Pada Tiga Lokasi di Kabupaten Malinau, Kalimantan Timur Kecamatan Timur. Buletin Kebun Raya 13(1): 3539.

Widjaja EA, Rahayuningsih Y, Rahajoe JS, Ubaidillah R, Maryanto I, Walujo EB \& Semiadi G. 2014. Kekinian Keanekaragaman Hayati Indonesia. LIPI Press. Jakarta. Pp: 111.

Wood JJ, Beaman RS \& Beamen JH. 1993. The Plants Of Mount Kinabalu. Royal Botanic Gardens. Kew. Pp: 411. 